\title{
PERBANDINGAN RISIKO CA SERVIKS BERDASARKAN PERSONAL HYGIENE PADA WANITA USIA SUBUR DI YAYASAN KANKER WISNUWARDHANA SURABAYA
}

\author{
CERVICAL CANCER RISK DIFFERENCE BASED ON PERSONAL \\ HYGIENE AMONG CHILDBEARING AGE WOMEN AT YAYASAN KANKER \\ WISNUWARDHANA SURABAYA
}

\section{Nessia Rachma Dianti, M.Atoillah Isfandiari}

Departemen Epidemiologi

Fakultas Kesehatan Masyarakat Universitas Airlangga, Kampus C Mulyorejo Surabaya

Email: nessiarachmadianti@yahoo.com

\begin{abstract}
About 500.000 cervical carcinoma new cases are found with more than 250.000 death cases annually (Rasjidi, 2009). Cervical cancer is the highest prevalence of disease among women in Indonesia, it is equal to 0,8\% (Kemenkes RI, 2015). Cervical cancer is caused by multifactors which are able to increase cervical cancer case, one of risk factors is personal hygiene. This study aims to analyze cervival cancer risk difference based on personal hygiene which consists of vaginal antiseptic usage, frequency of changing underpants, frequency of changing napkins, water utilization for vagina, public toilet utilization, vaginal discharge history, joint towel and underpants among childbearing women. This study is a case control study which case groups are 15-49 old women with cervical carcinoma, while control groups are 15-49 years old women and are undiagnosed cervical cancer. The result of this study showed that joint underpants has the highest Risk Difference $(R D=51.42 \%$; 95\% CI: 1.73-57.48). It is recommended for women to keep personal hygiene.
\end{abstract}

Keyword: personal Hygiene, Cervical Cancer, Cervical Cancer risk

\begin{abstract}
Abstrak: Setiap tahun, sebanyak 500.000 ditemukan kasus baru ca serviks dengan jumlah kematian lebih dari 250.000 (Rasjidi, 2009). Di Indonesia ca serviks merupakan penyakit dengan prevalensi tertinggi pada wanita yaitu sebesar 0,8\% (Kemenkes RI, 2015). Banyak faktor yang meningkatkan kejadian ca serviks salah satunya yaitu kebersihan diri. Studi ini bertujuan untuk menganalisis perbandingan besar risiko ca serviks berdasarkan kebersihan diri yang meliputi penggunaan antiseptik, frekuensi mengganti pembalut, frekuensi mengganti celana dalam, penggunaan air untuk organ kewanitaan, penggunaan toilet umum, riwayat keputihan, riwayat bertukar handuk dan riwayat bertukar celana dalam pada Wanita Usia Subur di Yayasan Kanker Wisnuwardhana Surabaya. Studi ini merupakan studi kasus kontrol dengan sampel kasus yaitu wanita usia subur berusia 15-49 tahun yang terdiagnosis ca serviks dan sampel kontrol yaitu wanita usia subur berusia 15-49 tahun dan tidak terdiagnosis ca serviks. Hasil dari studi ini menunjukkan bahwa riwayat bertukar pakaian dalam memiliki perbandingan besar risiko ca serviks terbesar (RD $=51.42 \%$; 95\% CI: 1.73-57.48), Dianjurkan kepada wanita untuk menjaga kebersihan diri.
\end{abstract}

Kata kunci: kebersihan diri, Kanker Serviks, risiko Kanker Serviks

\section{PENDAHULUAN}

Kanker merupakan salah satu penyebab kematian utama pada manusia di seluruh dunia. Data American Cancer Society (2008) menunjukkan bahwa sebesar 1.437 .180 kasus baru yang didiagnosis pada tahun 2008 dan hampir setengah dari kasus tersebut berujung pada kematian. Setiap tahunnya, sebanyak 500.000 kasus baru ca serviks ditemukan dengan jumlah kematian lebih dari 250.000 (Rasjidi, 2009). Di Indonesia sendiri, ca serviks merupakan penyakit dengan prevalensi tertinggi pada wanita yaitu sebesar 0,8\% (kemenkes RI, 2015). Menurut Diananda (2007), banyak faktor yang meningkatkan kejadian ca serviks yaitu faktor sosiodemografis meliputi usia, status sosial dan ekonomi, serta faktor aktivitas seksual meliputi usia pertama kali pada saat melakukan hubungan seks, riwayat berganti pasangan seks, paritas, kebersihan genital yang kurang, merokok, riwayat penyakit kelamin, trauma kronis pada serviks, serta penggunaan kontrasepsi oral dalam jangka waktu lebih dari 4 tahun. 
Sekitar 40.000 kasus ca serviks terjadi di Indonesia setiap tahunnya. Penyebab ca serviks utamanya adalah infeksi kronik oleh HPV (Human Papiloma Virus) namun faktor resiko ca serviks yang memicu sangatlah beragam salah satunya kebersihan diri yang buruk. Kebersihan diri yang buruk merupakan salah satu faktor risiko ca serviks, wanita yang memiliki kebersihan diri yang buruk memiliki risiko ca serviks 19,386 kali lebih besar daripada wanita yang memiliki kebersihan diri yang baik.

Berdasarkan estimasi, Provinsi Jawa Timur memiliki penderita kanker kedua terbanyak di Indonesia setelah Provinsi Jawa Tengah yaitu sekitar 61.230 kasus (Menkes RI, 2013). Provinsi Jawa Timur memiliki estimasi jumlah penderita ca serviks terbanyak nomor satu di Indonesia yaitu sekitar 5.668 kasus (Menkes RI, 2013). Menurut Kartikawati (2013), personal hygiene yang tidak baik serta penggunaan pembalut yang tidak berkualitas serta mengandung bahan pemutih (dioksin) dapat menguap apabila berekasi dengan darah menstruasi, hal ini berakibat pada penghambatan sirkulasi udara pada daerah kewanitaan. Penggunaan pantyliner seharihari juga dapat memperngaruhi kelembaban serta merangsang tumbuhnya bakteri pathogen yang dapat memicu ca serviks. Menurut Bustan (2007), perempuan dengan personal hygiene yang buruk memiliki risiko ca serviks lebih besar untuk terkena ca serviks daripada perempuan dengan personal hygiene yang baik.

Ca Serviks ini merupakan tumor ganas yang mengenai lapisan permukaan leher rahim yang disebut sel epitelskuamosa. Sel epitel skuamosa ini terletak antara rahim dan liang senggama. Tumor ganas yang terjadi disebabkan karena adanya penggandaan sel akibat berubahnya sifat sel menjadi sel yang tidak normal. Sifat dari sel ganas ini yaitu dapat menyebar atau metastasis ke bagian tubuh yang lain melalui pembuluh darah maupun getah bening sehingga merusak fungsi jaringan (Yatim, 2005). Penyebab utama ca serviks ini adalah infeksi dari virus bernama Human papilloma Virus (HPV). HPV yang sudah dapat teridentifikasi sampai saat ini yaitu sebanyak 138 jenis dan 40 di antaranya dapat ditularkan melalui hubungan seksual. Virus HPV yang dapat menyebabkan ca serviks yaitu virus HPV risiko sedang maupun tinggi. HPV risiko tinggi yang dapat menyebabkan pertumbuhan abnormal pada sel serviks adalah tipe $16,18,31,33,35,39,45,51$, 52, 56, 58, 59, 68, 69. Tipe virus HPV tersebut dapat menular lewat hubungan seksual. Beberapa penelitian menyatakan bahwa sebesar $90 \%$ ca serviks disebabkan oleh HPV tipe 16 dan 18. Dari kedua tipe ini, HPV tipe 16 telah menyebabkan lebih dari $50 \%$ ca serviks. Seseorang yang sudah terinfeksi virus HPV 16 maka memiliki kemungkinan terkena ca serviks sebesar 5\% (Rasjidi, 2009).

Faktor yang mempengaruhi ca seviks adalah usia pertama kali menikah, aktivitas seksual yang tinggi dan riwayat berganti pasangan, penggunaan antiseptik, rokok, paritas, penggunaan kontrasepsi oral dalam jangka waktu lama, dan personal hygiene yang buruk (Diananda, 2007).

Usia menikah $\leq 20$ tahun merupakan faktor yang mempengaruhi kejadian ca serviks karena sel mukosa belum benarbenar matang untuk melakukan hubungan seksual sehingga sangat rentan terhadap rangsangan dari luar. Busmar (1993), mengemukakan bahwa hubungan seksual pada usia muda akan meningkatkan risiko untuk terkena ca serviks, selain karena masih berkembangnya sel-sel serviks kemudian dipacu rangsangan dari sel mani yang berasal dari hubungan seksual. Sel mukosa baru benar-benar matang umumnya setelah wanita berusia di atas 20 tahun. Apabila sel-sel mukosa dalam rahim dipaksa untuk menerima rangsangan dari luar, hal ini berisiko untuk membentuk lesi pra kanker yang bisa menjadi kanker ditambah dengan zat-zat kimia yang terbawa oleh sperma. Sel mukosa serviks yang tidak siap menerima rangsangan dari luar bisa berubah sifat menjadi kanker. Selain itu, sel mukosa yang belum matang dapat tumbuh lebih banyak daripada sel yang mati apabila terlalu banyak menerima rangsangan dari luar. Pertumbuhan sel yang tidak seimbang dan abnormal ini akan berubah pula menjadi sel kanker.

Wanita dengan aktivitas seksual dan sering berganti-ganti pasangan akan 
memiliki risiko untuk mengalami ca serviks karena dengan semakin tinggi aktivitas seksual dan riwayat berganti-ganti pasangan akan memperbesar kemungkinan penularan penyakit kelamin serta memperbesar kemungkinan HPV masuk ke dalam rahim. Virus ini yang nantinya akan membuat sel mukosa menjadi abnormal sebagai pemicu kanker.

Faktor lain selain faktor riwayat seksual adalah merokok. Wanita yang merokok memiliki risiko 4-13 kali lebih besar untuk mengalami ca serviks daripada wanita yang tidak merokok. Hal ini dikarenakan nikotin dalam rokok mempermudah semua selaput lendir termasuk sel mukosa dalam rahim untuk menjadi terangsang. Rangsangan yang berlebihan ini akan memicu kanker. Namun tidak diketahui dengan pasti berapa jumlah nikotin yang mampu menyebabkan ca serviks.

Wanita yang sering melahirkan berisiko untuk terkena ca serviks, apalagi dengan jarak persalinan yang terlalu pendek. Semakin sering seorang wanita melahirkan, maka semakin besar risiko untuk terkena ca serviks karena semakin banyak lesi yang terdapat pada organ reproduksi dan memudahkan HPV masuk ke dalam rahim.

Penggunaan kontrasepsi oral selama lebih dari empat tahun akan meningkatkan risiko ca serviks sebesar 1,5-2,5 kali. Namun, efek dari penggunaan kontrasepsi oral terhadap ca serviks masih kontroversial karena ada beberapa penelitian yang gagal menemukan peningkatan risiko pada perempuan pengguna atau mantan pengguna kontrasepsi oral. Penelitian Wahyuningsih (2014), menemukan bahwa wanita yang menggunakan pil $\mathrm{KB}$ selama $\geq 4$ tahun memiliki risiko 42 kali untuk mengalami kejadian lesi prakanker serviks dibandingkan wanita yang menggunakan pil KB $<4$ tahun. Kontrasepsi berfungsi untuk mengatur jarak kelahiran maupun menekan angka kelahiran. Kontrasepsi oral ini umumnya adalah kombinasi dari estrogen dan progestin. Kurang lebih 100 juta perempuan di seluruh dunia menggunakan kontrasepsi oral kombinasi. Kontrasepsi oral kombinasi merupakan campuran estrogen sintetik seperti etinilestradiol dan satu dari beberapa steroid C19 dengan aktivitas progesteron noretindron. Kontrasepsi ini mengandung dosis estrogen dan progesteron yang tetap. Penggunaan pil KB berisiko ca serviks karena pemakaian estrogen yang terkandung dalam pil KB merangsang terjadinya penebalan dinding endometrium dan dapat merangsang selsel endometrium berubah sifat menjadi sel kanker (Wahyuningsih, 2014). Hal ini juga didukung oleh penelitian Melva pada tahun 2008 di RSUD Dr.Moewandi Surakarta yang menemukan bahwa $60 \%$ penderita kanker adalah wanita yang menggunakan pil kontrasepsi lebih dari 4 tahun.

Organ reproduksi wanita mudah terkena bakteri yang dapat menyebabkan bau tak sedap dan infeksi di daerah kelamin. Oleh karena itu, wanita perlu menjaga kebersihan organ reproduksi antara lain mencuci vagina setiap hari dengan cara membasuh dari arah depan ke belakang atau dari vagina ke anus secara hati-hati menggunakan air yang bersih. Selain itu, untuk menjaga kebersihan organ kelamin wanita sebaiknya mengeringkan organ kewanitaan dengan lap bersih setelah membasuh organ kelamin. Hal ini berguna untuk menghindari tumbuhnya jamur karena kelembababan yang berlebihan. Upaya untuk mencegah ca serviks lain juga dapat dilakukan dengan mengganti celana dalam minimal dua kali sehari, menghindari penggunaan antiseptik dan bertukar pakaian dalam serta handuk dengan orang lain. Wanita dianjurkan untuk mengganti pembalut secara teratur 4-5 kali sehari serta sebaiknya memilih pembalut yang berbahan lembut dan dapat menyerap dengan baik (Rahmayanti, 2012). Menurut Sukaca (2009), penggunaan antiseptik yang terlalu sering dapat menyebabkan iritasi pada vagina yang dapat memicu kanker serviks, selain itu iritasi ini akan merangsang terjadinya perubahan sel yang menyebabkan kanker. Menurut Busmar (1993), kebersihan genitalia yang kurang pada seorang wanita akan meningkatkan bakteri patogen dalam vagina sehingga memicu penyakit salah satunya yaitu ca serviks.

Menurut penelitian Indrawati dan Fitriyani (2012), personal hygiene yang kurang baik memiliki risko untuk terkena ca seriks 19,386 kali lebih besar dibandingkan dengan wanita yang memiliki personal 
hygiene yang baik. Menurut Elistiawaty (2006), wanita yang mengalami keputihan memiliki jumlah yang sangat besar di Indonesia. Sebanyak 75\% wanita Indonesia pasti mengalami keputihan minimal satu kali dalam hidupnya. Berbeda dengan Eropa yang memiliki angka keputihan pada wanita yang hanya sebesar $25 \%$. Hal ini dikarenakan kondisi cuaca Indonesia yang lembab dan dapat mudah terinfeksi jamur. Keputihan biasa dianggap sepele, padahal keputihan bisa menjadi sangat fatal bila terlambat ditangani, keputihan juga dapat menjadi gejala awal dari ca serviks yang bisa berujung pada kematian (Indriyani, 2012).

Menurut penelitian Indrawati dan Fitriyani (2012), kebersihan diri yang kurang baik memiliki risiko untuk terkena ca serviks 19,386 kali lebih besar dibandingkan dengan wanita yang memiliki personal hygiene yang baik. Ca serviks dapat disebabkan oleh HPV yang berasal dari toilet umum ketika virus HPV ada pada tangan seorang wanita lalu menyentuh daerah genital sehingga virus ini dapat berpindah dan menginfeksi serviks. Seorang penderita kanker ini juga dapat memindahkan virus HPV melalui closet (Wulandari, 2010).

Banyaknya faktor personal hygiene yang menjadi faktor risiko ca serviks, maka peneliti merasa penting untuk melakukan penelitian terkait perbandingan besar risiko ca serviks berdasarkan personal hygiene. Penelitian ini bertujuan untuk menganalisis perbandingan besar risiko ca serviks terbesar berdasarkan personal hygiene yang terdiri dari penggunaan antiseptik, frekuensi mengganti pembalut, frekuensi mengganti celana dalam, penggunaan air untuk organ kewanitaan, penggunaan toilet umum, riwayat keputihan, riwayat bertukar handuk dan riwayat bertukar celana dalam pada Wanita Usia Subur di Yayasan Kanker Wisnuwardhana Surabaya.

\section{METODE}

Studi ini merupakan penelitian observasional dengan metode penelitian kasus kontrol. Penelitian ini dilaksanakan di Yayasan Kanker Wisnuwardhana Surabaya pada bulan Januari-Mei 2016.
Populasi penelitian terdiri dari sampel kasus dan sampel kontrol. Sampel kasus yaitu seluruh pasien Wanita Usia Subur berusia 15-49 tahun yang terdaftar di rekam medik Yayasan Kanker Wisnuwardhana Surabaya pada bulan Januari 2015-Mei 2016, terdiagnosis ca seriks, sedang menderita ca serviks dan bersedia menjadi responden. Sementara sampel kontrol yaitu seluruh wanita usia subur berusia 15-49 tahun yang tidak terdiagnosa ca serviks dan bersedia menjadi responden. Kriteria eksklusi sampel kasus adalah seluruh pasien wanita yang memiliki keluarga dengan riwayat ca serviks, seluruh pasien wanita yang memiliki riwayat penyakit kelamin, seluruh pasien wanita dengan ca serviks stadium 4 dan tidak mampu secara fisik dan mental untuk menjadi responden.

Penelitian ini menggunakan perbandingan sampel kasus dan sampel kontrol sebesar 1:3 sehingga dari rumus di atas diperoleh jumlah sampel minimal sampel kasus yaitu sebesar 18 orang dan sampel sampel kontrol sejumlah 18x3 yaitu sebanyak 54 orang. Cara pengambilan sampel yaitu purposive sampling. Pengambilan sampel kasus yaitu dengan meninjau rekam medik Yayasan Kanker Wisnuwardhana Surabaya pada bulan Januari 2015-Mei 2016 dan memilah sampel dengan berbagai kriteria tertentu. Kriteria sampel kasus yaitu wanita yang terdiagnosa ca serviks dan berusia 15-49 tahun. Sementara untuk sampel kontrol merupakan wanita yang berusia 15-49 tahun, tidak terdiagnosa ca serviks dan bersedia menjadi responden. Pengambilan sampel kontrol yaitu dengan memilih sampel WUS yang sedang mengunjungi Yayasan Kanker Wisnuwardhana Surabaya. Variabel bebas meliputi kebersihan diri yang terdiri dari penggunaan antiseptik, frekuensi mengganti pembalut, frekuensi mengganti celana dalam, penggunaan air untuk organ kewanitaan, penggunaan toilet umum, riwayat keputihan, riwayat bertukar handuk dan riwayat bertukar celana dalam. Data yang digunakan merupakan data primer dan data sekunder. Data primer berasal dari hasil pengisian kuisioner responden, sementara data sekunder diperoleh dari laporan rekapitulasi di bagian rekam medik 
Yayasan Kanker Wisnuwardhana Surabaya. Pengumpulan data primer dilakukan dengan cara penyebaran kuisioner secara langsung. Sedangkan pengumpulan data sekunder diperoleh dari laporan rekapitulasi di bagian rekam medik Yayasan Kanker Wisnuwardhana Surabaya. Setelah data terkumpul, data dianalisis dengan menggunakan aplikasi Epi Info. Pengolahan data terdiri dari beberapa proses yakni editing, yaitu mengkaji dan meneliti data yang telah terkumpul dari hasil pengisian kuisioner, entry yaitu memasukkan data ke dalam computer untuk dianalisis lebih lanjut, coding yaitu pemberian kode pada data untuk mempermudah dalam proses analisis, dan tabulating yaitu merekap dan menyusun data yang telah dimasukkan ke dalam program komputer dalam bentuk tabel untuk mempermudah membaca data. Data dianalisis dengan mencari Odds Ratio (OR) dari setiap variabel untuk terkena ca serviks dan mencari Risk Difference (RD) untuk melihat perbedaan risiko antara antara kelompok terpapar dan kelompok yang tidak terpapar. OR merupakan rasio antara risiko terkena penyakit pada kelompok yang terpapar (exposed) dan risiko terkena penyakit pada kelompok yang tidak terpapar (non-exposed). Jika nilai OR $=1$ maka variabel yang diduga sebagai faktor risiko tidak ada pengaruh dalam terjadinya efek, atau dengan kata lain bukan sebagai faktor risiko terjadinya efek (penyakit atau masalah kesehatan). Apabila nilai OR $>1$ dan rentang interval kepercayaan tidak mencakup angka 1 , berarti variabel tersebut sebagai faktor risiko terjadinya efek. Sementara itu, jika nilai $\mathrm{OR}<1$ dan rentang interval kepercayaan tidak mencakup angka satu, berarti faktor yang diteliti merupakan faktor protektif untuk terjadinya efek. Jika nilai interval kepercayaan OR mencakup nilai 1 maka berarti mungkin $\mathrm{OR}=1$, sehingga belum dapat disimpulkan bahwa faktor yang diteliti merupakan faktor risiko atau faktor protektif (Nugrahaeni, 2010).

\section{HASIL PENELITIAN}

Yayasan Kanker Wisnuwardhana Surabaya adalah suatu lembaga sosial swadaya masyarakat yang bergerak dalam bidang kesehatan khususnya kanker. Sasarannya merupakan seluruh lapisan masyarakat terutama keluarga yang merupakan unit terkecil dari masyarakat, tenaga medis dan para medis. Aktivitas dari yayasan ini terdiri dari pencegahan primer melalui Pendidikan Kanker Profesi (PKP) dan Pendidikan Kanker Masyarakat (PKM), deteksi dini kanker, pengobatan komplementer dan alternatif untuk kanker, keluarga berencana perkotaan, kerjasama dengan bidang-bidang terkait, serta kegiatan ilmiah penelitian.

Yayasan Kanker Wisnuwardhana Surabaya terbentuk karena timbulnya penyakit kanker yang multi kompleks serta mempunyai dampak yang luas terhadap masyarakat maupun dunia kedokteran. Hal tersebut melatarbelakangi agar terbentuknya deteksi dini kanker yang ada di Yayasan ini.

Berdasarkan penelitian yang telah dilakukan, karakteristik umur WUS pada sampel kasus sebgaian besar berusia 3552 tahun. Sedangkan pada sampel kontrol sebagian besar berusia 35-43 tahun. Karakteristik pendidikan baik pada sampel kasus maupun sampel kontrol yaitu sebagian besar tamat SMA/sederajat. Sementara karakteristik pekerjaan baik pada sampel kasus maupun sampel kontrol yaitu sebagian besar memiliki pekerjaan sebagai ibu rumah tangga.

Tabel 1. Karakteristik Responden

\begin{tabular}{lcc}
\hline Karakteristik & kasus (\%) & kontrol (\%) \\
\hline Usia & & \\
17-25 tahun & 11.20 & 9.4 \\
26-34 tahun & 22.40 & 16.9 \\
35-43 tahun & 33.50 & 35.48 \\
44-52 tahun & 33.50 & 39 \\
\hline Pendidikan & & \\
SD & 27.80 & 1.90 \\
SMP & 11.10 & 14.80 \\
SMA & 44.40 & 38.90 \\
Perguruan & 16.70 & 44.40 \\
Tinggi & & \\
\hline Pekerjaan & & \\
Pedagang/tani & 11.10 & 1.90 \\
Pegawai swasta & 22.20 & 33.30 \\
Pelajar & 0 & 3.70 \\
PNS & 5.60 & 22.20 \\
Lain-lain & 5.60 & 5.60 \\
Tidak bekerja & 55.60 & 33.30 \\
\hline
\end{tabular}


Sebagian besar sampel kasus menggunakan antiseptik organ kewanitaan pada kehidupan sehari-hari, sementara pada sampel kontrol sebagian besar tidak menggunakan antiseptik organ kewanitaan pada kehidupan sehari-hari. Sebagian besar sampel kasus mengganti pembalut sebanyak kurang dari 4 kali dalam sehari, sementara pada sampel kontrol sebagian mengganti pembalut sebanyak lebih dari sama dengan 4 kali sehari dan sebagian lagi mengganti pembalut sebanyak kurang dari 4 kali. Baik sampel kasus maupun sampel kontrol sebagian besar mengganti celana dalam sebanyak kurang dari 3 kali. Sebagian besar sampel kasus menggunakan toilet umum pada kehidupan sehari-hari. Hal ini disebabkan karena responden ada yang bekerja, sehingga menggunakan toilet umum pada kehidupan sehari-hari. Sementara itu, pada sampel kontrol sebagian besar tidak menggunakan toilet umum. Baik sampel kasus maupun sampel kontrol menggunakan air bersih untuk membasuh organ kewanitaan pada kehidupan sehari-hari. Sebagian besar sampel kasus mengalami keputihan yang abnormal. Sementara itu, pada sampel kontrol sebagian besar

Tabel 2. Perbandingan Besar Risiko Ca Serviks Berdasarkan Riwayat Personal Hygiene pada WUS di Yayasan Kanker Wisnuwardhana Surabaya

\begin{tabular}{|c|c|c|c|c|c|}
\hline \multirow[b]{2}{*}{ Personal Hygiene } & Kasus & Kontrol & \multirow{2}{*}{$\begin{array}{c}\text { Odds Ratio } \\
\text { (OR) } \\
\text { (95\% CI) }\end{array}$} & \multirow[b]{2}{*}{ p value } & \multirow{2}{*}{$\begin{array}{c}\text { Risk } \\
\text { Difference } \\
\text { (RD) }\end{array}$} \\
\hline & n (\%) & n $(\%)$ & & & \\
\hline \multicolumn{6}{|l|}{ Penggunaan antiseptik } \\
\hline $\mathrm{Ya}$ & $12(66.7 \%)$ & $21(38.9 \%)$ & 3.14 & \multirow{3}{*}{0.07} & \multirow{3}{*}{$20.97 \%$} \\
\hline Tidak & $6(33.3 \%)$ & $33(61.1 \%)$ & $(1.02-9.65)$ & & \\
\hline Jumlah & $18(100 \%)$ & $54(100 \%)$ & & & \\
\hline \multicolumn{6}{|c|}{$\begin{array}{l}\text { Frekuensi mengganti pembalut } \\
\text { dalam sehari }\end{array}$} \\
\hline$<4$ kali & $13(72.2 \%)$ & $27(50 \%)$ & \multirow{3}{*}{$(0.81-8.30)$} & \multirow[t]{3}{*}{0.17} & \multirow[t]{3}{*}{$16.87 \%$} \\
\hline$\geq 4$ kali & $5(27.8 \%)$ & $27(50 \%)$ & & & \\
\hline Jumlah & $18(100 \%)$ & $54(100 \%)$ & & & \\
\hline \multicolumn{6}{|l|}{ Frekuensi mengganti celana } \\
\hline$<3$ kali & $16(88.9 \%)$ & $33(61.1 \%)$ & $\begin{array}{l}5.09 \\
(10624.12)\end{array}$ & \multirow{3}{*}{0.05} & \multirow[t]{3}{*}{$23.95 \%$} \\
\hline$\geq 3$ kali & $2(11.1 \%)$ & $21(38.9 \%)$ & & & \\
\hline Jumlah & $18(100 \%)$ & $54(100 \%)$ & & & \\
\hline \multicolumn{6}{|l|}{ Penggunaan toilet umum } \\
\hline Ya & $15(83.3 \%)$ & $19(35.2 \%)$ & 9.21 & \multirow{3}{*}{0.00} & \multirow{3}{*}{$36.22 \%$} \\
\hline Tidak & $3(16.7 \%)$ & $35(64.8 \%)$ & $(2.36-35.87)$ & & \\
\hline Jumlah & $18(100 \%)$ & $54(100 \%)$ & & & \\
\hline \multicolumn{6}{|l|}{ Penggunaan air } \\
\hline Air bersih & $14(77.8 \%)$ & $52(96.3 \%)$ & 0.13 & \multirow{3}{*}{0.03} & \\
\hline Air kotor & $4(22.2 \%)$ & $2(3.7 \%)$ & $(0.02-0.81)$ & & \\
\hline Jumlah & $18(100 \%)$ & $54(100 \%)$ & & & \\
\hline \multicolumn{6}{|l|}{ Riwayat keputihan } \\
\hline Normal & $3(16.7 \%)$ & $34(63 \%)$ & 8.50 & \multirow{3}{*}{0.00} & \multirow{3}{*}{$34.74 \%$} \\
\hline Tidak normal & $15(83.3 \%)$ & $20(37 \%)$ & $(2.18-33.02)$ & & \\
\hline Jumlah & $18(100 \%)$ & $54(100 \%)$ & & & \\
\hline \multicolumn{6}{|c|}{ Riwayat bertukar pakaian dalam } \\
\hline Ya & $5(27.8 \%)$ & $2(3.7 \%)$ & 10 & \multirow{3}{*}{0.11} & \multirow{3}{*}{$51.42 \%$} \\
\hline Tidak & $13(72.2 \%)$ & $52(96.3 \%)$ & $(1.73-57.48)$ & & \\
\hline Jumlah & $18(100 \%)$ & $54(100 \%)$ & & & \\
\hline \multicolumn{6}{|l|}{ Riwayat bertukar handuk } \\
\hline Ya & $12(66.7 \%)$ & $15(27.8 \%)$ & 5.20 & \multirow{3}{*}{0.00} & \multirow{3}{*}{$31.11 \%$} \\
\hline Tidak & $6(33.3 \%)$ & $39(72.2 \%)$ & $(1.65-16.36)$ & & \\
\hline Jumlah & $18(100 \%)$ & $54(100 \%)$ & & & \\
\hline
\end{tabular}


mengalami keputihan yang normal. Data pada penelitian ini mengarah pada keputihan fisiologis yaitu keputihan yang normal terjadi pada wanita saat ovulasi, menjelang haid dan sesudah haid. Selain itu keputihan secara normal yaitu keputihan yang bening, tidak bau, dan tidak gatal (Julina, 2012). Sebagian besar sampel kasus mengalami keputihan yang abnormal yaitu sebanyak 15 orang. Sementara itu, pada sampel kontrol sebagian besar mengalami keputihan yang normal yaitu sebanyak 34 orang. Data pada penelitian ini mengarah pada keputihan fisiologis yaitu keputihan yang normal terjadi pada wanita saat ovulasi, menjelang haid dan sesudah haid. Selain itu keputihan secara normal yaitu keputihan yang bening, tidak bau, dan tidak gatal (Julina, 2012).

Sebagian besar sampel kasus mengaku bertukar handuk mandi dengan orang lain, sementara pada sampel kontrol sebagian besar mengaku tidak bertukar handuk dengan orang lain.

Berdasarkan penelitian yang telah dilakukan, perbandingan besar risiko (RD) terbesar yaitu berdasarkan riwayat bertukar pakaian dalam. Hal ini berarti bahwa perbandingan besar risiko ca serviks antara wanita usia subur di Yayasan Kanker Wisnuwardhana Surabaya yang memiliki riwayat bertukar pakaian dalam dengan wanita usia subur yang tidak memiliki riwayat bertukar pakaian dalam yaitu sebesar $51.42 \%$.

Berdasarkan tabel 2, perbandingan besar risiko $(\mathrm{RD})$ terkecil yaitu berdasarkan frekuensi mengganti pembalut dalam sehari. Hal ini berarti bahwa perbandingan besar risiko ca serviks antara WUS di Yayasan Kanker Wisnuwardhana Surabaya yang mengganti pembalut rata-rata sebanyak $<4$ kali dalam sehari dengan WUS yang mengganti pembalut rata-rata sebanyak $\geq 4$ kali dalam sehari yaitu sebesar $16.87 \%$.

Berdasarkan penelitian yang telah dilakukan, penggunaan toilet umum merupakan faktor risiko terbesar untuk terjadinya ca serviks pada WUS di Yayasan Kanker Wisnuwardhana Surabaya. Hal ini berarti WUS di Yayasan Kanker Wisnuwardhana Surabaya yang menggunakan toilet umum pada kehidupan sehari-hari memiliki risiko 9.21 kali lebih besar untuk terkena ca serviks daripada WUS yang tidak menggunakan toilet umum. Faktor risiko ca serviks terkecil adalah frekuensi mengganti pembalut $<4$ kali dalam sehari. Hal ini berarti bahwa WUS di Yayasan Kanker Wisnuwardhana Surabaya yang rata-rata mengganti pembalut sebanyak $<4$ kali dalam sehari memiliki risiko ca serviks 2.60 kali lebih besar daripada WUS yang rata-rata mengganti pembalut sebanyak $\geq 4$ kali. Namun, angka ini tidak bermakna secara epidemiologi.

\section{PEMBAHASAN}

Penggunaan antiseptik merupakan risiko untuk terkena ca serviks. Hal ini sesuai dengan teori Sukaca (2009), bahwa penggunaan antiseptik merupakan salah satu faktor risiko untuk terkena ca serviks. Penggunaan antiseptik yang terlalu sering akan menyebabkan iritasi pada vagina yang memicu terjadinya kanker. Selain itu, antiseptik akan merangsang perubahan sel yang pada akhirnya akan berubah menjadi kanker. Hal ini juga sesuai dengan teori yang dikemukakan Diananda (2007), bahwa mencuci vagina dengan obatobatan antiseptik ataupun deodoran akan mengakibatkan iritas pada serviks yang merangsang terjadinya kanker.

Frekuensi mengganti pembalut sebagai risiko ca serviks lebih dihubungkan dengan menjaga kebersihan organ genital. Penggantian pembalut secara teratur dapat mencegah bakteri patogen yang memicu timbulnya penyakit. Pembalut memang merupakan benda yang sangat penting bagi wanita ketika seorang wanita sedang mengalami mentruasi, namun tanpa disadari, pembalut wanita ini merupakan salah satu penyebab penyakit kewanitaan karena adanya zat dioxin yang dapat menyebabkan kanker menurut WHO (Pitriani, 2013). Hal ini juga didukung dengan penelitian Tartylah (2010) bahwa sangat dianjurkan seorang wanita untuk mengganti pembalut secara teratur 4-5 kali sehari atau setelah buang air kecil atau mandi untuk menghindari tumbuhnya jamur atau bakteri.

Salah satu upaya untuk mencegah ca serviks adalah dengan mengganti celana dalam secara teratur. Berdasarkan penelitian 
yang telah dilakukan, mengganti celana dalam $<3$ kali merupakan faktor risiko dari ca serviks. Hal ini sesuai dengan teori karena mengganti celana dalam minimal dua kali sangat penting untuk menjaga dan mempertahankan kesehatan dengan memelihara kesehatan reproduksi (Tartylah, 2010). Mengganti celana dalam minimal dua kali sehari adalah salah satu usaha untuk menjaga kebersihan diri agar tetap bersih terutama organ kewanitaan karena berdasarkan Asmino \& Sudoko dalam Susanti (2010), kebersihan genital rendah dapat menyebabkan berbagai penyakit pada serviks seperti infeksi, luka dan sebagainya yang meningkatkan risiko ca serviks. Hal ini juga didukung pada penelitian Irene, et.al (2005), bahwa perilaku kebersihan alat kelamin pada kebersihan perseorangan mempunyai hubungan yang bermakna dengan kejadian ca serviks dengan OR sebesar 102, 8 .

Penularan ca serviks dari satu orang ke orang yang lain tidak hanya secara seksual namun bisa juga secara non seksual. Jalur penularan non seksual bisa terjadi ketika seorang wanita menggunakan toilet umum. Oleh karena itu, untuk mencegah penularan ca serviks melalui jalur non seksual ini, seorang wanita dapat melakukan kewaspadaan dalam menjaga kebersihan organ saat menggunakan toilet umum di kantor, pasar, dan tempat umum lainnya (Septadiana dkk, 2015). Selain itu, hal ini juga didukung dengan penelitian Dewi dkk (2013), bahwa HPV penyebab ca serviks dapat menular melalui toilet umum, terutama toilet duduk karena Virus HPV menempel pada mulut WC sehingga bisa menularkan dari satu wanita ke wanita lain yang menggunakan toilet tersebut dan akan menyebabkan ca serviks. Menurut Rimawati dkk (2012), toilet umum juga dapat menjadi salah satu penularan infeksi melalui HPV, bakteri dan kuman yang terkandung dalam air maupun pada mulut WC. Ketika berada di toilet umum, air yang berada di ember atau air yang menggenang lebih berisiko untuk menyebabkan ca serviks karena air yang tergenang mengandung jamur candida albicans sebesar $70 \%$, sementara air yang mengalir dalam keran mengandung kurang lebih hanya $10-20 \%$.
Riwayat penggunaan air bukan merupakan faktor risiko dari ca serviks pada WUS di Yayasan Kanker Wisnuwardhana Surabaya.Hal ini tidak sesuai dengan teori karena air yang kotor dapat menjadi media penyebab ca serviks apabila di dalam air terkandung HPV dan masuk ke dalam serviks (Anonim, 2014). Beberapa faktorfaktor pemicu selain penggunaan air yang tidak bersih karena organ reproduksi mudah terkena bakteri dan infeksi yang dapat menyebabkan bau tak sedap pada organ kelamin. Wanita perlu menjaga kebersihan organ reproduksi antara lain mencuci vagina setiap hari dengan cara membasuh dari arah depan ke belakang atau dari vagina ke anus secara hati-hati menggunakan air yang bersih. Setelah membasuh alat kelamin, sebaiknya wanita perlu mengeringkan organ kelamin dengan handuk atau lap yang bersih sebelum memakai pakaian dalam untuk menghindari kelembaban yang berlebihan yang mampu menyebabkan tumbuhnya jamur (Diananda, 2007).

Keputihan merupakan salah satu risiko dari ca serviks berdasarkan penelitian yang telah dilakukan. Hal ini sesuai dengan teori karena keputihan yang tidak normal seperti keputihan yang berbau, berwarna dan menyebabkan gatal merupakan salah satu tanda gejala awal penyakit infeksi organ reproduksi wanita termasuk ca serviks. Keputihan juga merupakan faktor risiko atau penyebab ca serviks yaitu keputihan yang bau dan gatal, dan berlangsung secara terus-menerus (Julina, 2012). Keputihan ini merupakan gejala yang sering ditemukan. Lendir yang keluar dari vagina ini makin lama akan berbau busuk akibat infeksi dan nekrosis pada jaringan (Pitriani, 2013).

Bertukar pakaian dalam dengan orang lain akan berpotensi menularkan penyakit, infeksi, bakteri dan virus termasuk HPV. Menurut Rahmayanti (2012), bertukar pakaian dalam dengan orang lain adalah sesuatu yang perlu dihidari, selain untuk mencegah penularan penyakit, mencegah bertukar pakaian dalam adalah suatu usuaha untuk menjaga kebersihan diri mengingat banyak penelitian yang telah membuktikan bahwa personal hygiene memiliki hubungan dengan ca serviks, seperti pada penelitian Indrawati dan Fitriyani (2012) personal 
hygiene yang kurang baik memiliki risiko terkena ca serviks sebesar 19.386 kali lebih besar daripada wanita dengan personal hygiene yang baik.

Penularan HPV, jamur dan bakteri bisa masuk ke serviks melalui handuk dari satu orang ke orang yang lain. Mikoorganisme patogen dapat menular melewati handuk. Mikroorganisme ini yang dapat menyebabkan infeksi.Infeksi menahun pada mulut rahim karena kurangnya kebersihan genital dapat menimbulkan timbulnya ca serviks menurut Asmino dan Soedoko dalam Susanti (2010). Bertukar pakaian handuk juga merupakan sesuatu yang perlu dihindari untuk pencegahan penularan penyakit dan menjaga kebersihan diri (Rahmayanti, 2012).

\section{SIMPULAN}

Perbandingan besar risiko ca serviks berdasarkan personal hygiene terbesar pada WUS di Yayasan Kanker Wisnuwardhana Surabaya adalah berdasarkan riwayat bertukar pakaian dalam. Hal ini berarti bahwa perbandingan besar risiko ca serviks antara wanita usia subur di Yayasan Kanker Wisnuwardhana Surabaya yang memiliki riwayat bertukar pakaian dalam dengan wanita usia subur yang tidak memiliki riwayat bertukar pakaian dalam yaitu sebesar $51.42 \%$. Sementara perbandingan besar risiko ca serviks terkecil adalah berdasarkan frekuensi mengganti pembalut dalam sehari. Hal ini berarti bahwa perbandingan besar risiko ca serviks antara WUS di Yayasan Kanker Wisnuwardhana Surabaya yang mengganti pembalut ratarata sebanyak $<4$ kali dalam sehari dengan WUS yang mengganti pembalut rata-rata sebanyak $\geq 4$ kali dalam sehari yaitu sebesar $16.87 \%$, namun tidak bermakna secara epidemiologi.

\section{SARAN}

Wanita disarankan untuk menghindari bertukar pakaian dalam dengan orang lain untuk mencegah ca serviks. Selain itu juga wanita dianjurkan untuk menjaga personal hygiene salah satunya dengan menghindari penggunaan antiseptik kewanitaan pada kehidupan sehari-hari, mengganti pembalut sebaiknya sebanyak 4 kali atau lebih, mengganti celana dalam sebanyak 3 kali atau lebih, menggunakan air bersih untuk membasuh organ kewanitaan dan menghindari bertukar handuk dengan orang lain.

Yayasan Kanker Wisnuwardhana Surabaya disarankan untuk mengembangkan perencanaan pencegahan kanker serviks dengan menambahkan media promosi kesehatan seperti poster dan video edukasi serta sosialisasi tentang pencegahan ca serviks dan pentingnya menjaga personal hygiene.

\section{DAFTAR PUSTAKA}

American Cancer Society, 2008.Cancer fact and figure.http://www.cancer.org/ downloads/STT/2008 [sitasi 3 Juni 2016]

Anonim. 2014. Air Kotor Bisa Menjadi Media Penularan Kanker Serviks. Tersedia di:http://rhizomananopropolis.com/860/ air-kotor-bisa-menjadi-media-penularankanker-serviks/ [sitasi 9 juni 2016]

Busmar, B. 1993. Kanker leher rahim. Kumpulan naskah lengkap simposium kanker pembunuh nomor satu. Jakarta

Bustan, M.N. 2007. Epidemiologi Penyakit Tidak Menular. Jakarta: Rineka Cipta

Dewi, I.G.A.A.N., Sawitri, A.A.S., Adiputra, N. 2013. Paparan Asap Rokok dan Higieni Diri Merupakan Faktor Risiko Lesi Prakanker Leher Rahim di Kota Denpasar Tahun 2012. Public Health and Preventive Medicine Archive. 1(1).

Diananda, R. 2007. Mengenal Seluk Beluk Kanker. Yogyakarta : Katahati.

Elistiawaty. 2006. 75\% Wanita RI Alami Keputihan. http://www.detiknews.com/ index.php/detik. [sitasi 9 juni 2016].

Indrawati, T., Fitriyani, H. 2012. Hubungan Personal Hygiene Organ Genital dengan Kejadian Kanker Serviks di RSUP Dr. Kariyadi Kota Semarang. Dinamika Kebidanan. 2(1).

Indriyani, R., Indriyawati, Y., Pratiwi, IGD. 2012. Hubungan Personal Hygiene dengan Kejadian Keputihan pada Siswi MAAl-Hikmah Aeng Deke Bluto.Jurnal kesehatan Wiraraja Medika. http:// 
ejournal.wiraraja.ac.id/index.php/FIK/ article/download/44/25. [sitasi 2 juni 2016].

Irene, et al 2007. Faktor yang Berhubungan dengan Kejadian Infeksi Saluran Reproduksi pada Istri Sopir Truk Tangki Dua Perusahaan di Propinsi Sumatera Barat. Jakarta: Medika

Julina. 2012. Analisis Perilaku Konsumen Perempuan Terhadap Kesehatan Reproduksi dan Perilaku Penggunaan Pembalut. http://ejournal.uin-suska. ac.id/index.php/marwah/article/ download/498/478 [sitasi 9 juni 2016]

Kartikawati, E. 2013. Awas!!! Bahaya Kanker Payudara \& Kanker Serviks. Bandung : Buku Baru

Kementrian Kesehatan, RI. 2015. INFODATIN KANKER. Jakarta: Pusat Data dan Informasi Kemenkes RI

Nugrahaeni, D.K. 2010. Konsep Dasar Epidemiologi. Jakarta: EGC

Pitriani. 2013. Faktor Risiko Kejadian Kanker Serviks Pada Pasien Rawat Inap di RSUP Dr. Wahidin Sudirohusodo Makassar. Tesis. Universitas Hasanuddin

Rahmayanti, N. 2012. Perilaku Perawatan Kebersihan Alat Reproduksi dalam Pencegahan Kaner Serviks pada Siswi SMAN 9 Kebon Pala Jakarta Timur. Skripsi. Universitas Indonesia

Rasjidi, I. 2009. Epidemiologi Kanker Serviks. Indonesian Journal of Cancer, 3: pp. 103

Rimawati, E., Kusuma, A.P., Sunaryati, S. 2012. Kebersihan Organ Reproduksi pada Perempuan Pedesaan di Kelurahan Polaman Kecamatan Mijen Semarang, Universitas Dian Nuswantoro. http:// publikasi.dinus.ac.id/index.php/visikes/ article/view/658. [sitasi 2 Juni 2014]

Septadiana, I.S, Kesuma, H., Handayani, D, dkk. 2015. Upaya Pencegahan Kanker Serviks Melalui Peningkatan Pengetahuan Kesehatan Reproduksi Wanita dan Pemeriksaan Metode IVA (Inspeksi Visual Asam Asetat) di Wilayah Kerja
Puskesmas Kenten Palembang. Jurnal Pengabdian Sriwijaya, [e-journal] 3(1). http://ejournal.unsri.ac.id/index.php/ jpsriwijaya/article/download/2149/935 [sitasi 10 juni 2016].

Sukaca, B.E. 2009. Cara Cerdas Menghadapi Kanker Serviks. Yogyakarta: Genius Publisher

Susanti, I. 2010. Hubungan Usia Pertama Kali Berhubungan Seksual dan Jumlah Pasangan Seksual dengan Kejadian Lesi Pra Kanker Leher Rahim Pada Wanita yang Melakukan Deteksi Dini Menggunakan MetodeInspeksi Visual Dengan Asam Asetat (IVA) di Puskesmas Cikampek, Pedes dan Kota Baru Kabupaten Karawang Tahun 20092010. Tesis. Universitas Indonesia

Syatriani, S. 2011. Faktor Risiko Kanker Serviks di Rumah Sakit Umum Pemerintah Dr. Wahidin Sudirohusodo Makassar, Sulawesi Selatan. Jurnal Kesehatan Masyarakat Nasional, 5 (6): pp. 284

Tartylah. 2010. Personal Hygiene Selama Menstruasi. Jakarta: Salemba Medika

Wahyuningsih,T., Mulyani, E.Y. 2014. Faktor Risiko Terjadinya Lesi Prakanker Serviks Melalui Deteksi Dini dengan Metode IVA (Inspeksi Visual dengan Asam Asetat). Forum ilmiah, 1(2)

Wulandari, A.S. 2010. Pengertian dan Pemahaman Resiko Ca Servix pada Wanita Usia Subur di Indonesia, Jurnal Universitas Wijaya Kusuma Surabaya. http://elib.fk.uwks.ac.id/asset/ archieve/jurnal/Vol2.no1.Januari2010/ P E N GERT I A N \% 20 D A N \% 20 PEMAHAMAN \%20RESIKO \% 20 CA\%20CERVIX\%20PADA.pdf [sitasi 9 juni 2016].

Yatim, F. 2005. Penyakit kandungan: myoma, kanker rahim/leher rahim dan indung telur, kista, serta gangguan lainnya. Jakarta : Pustaka Populer Obor 